\title{
The importance of spring hunting in Malta on European Turtle-Dove Streptopelia turtur and Common Quail Coturnix coturnix populations
}

\author{
PAUL CARUANA-GALIZIA and NATALINO FENECH
}

\begin{abstract}
Summary
The European Commission's 1979 Wild Birds Directive bans member states from hunting wild birds during spring, the period during which they are breeding or migrating, as hunting wild birds before they have reproduced is perceived to have a greater effect on bird populations than it would in autumn or winter. Malta is the only European Union member state to allow recreational wild bird hunting in spring, when birds migrate over the country to their European breeding grounds. Malta's derogation of the European Commission's ban can only be legally permissible if no alternative solutions to spring hunting exist. Using figures provided by hunters, we show that greater numbers of European Turtle-dove Streptopelia turtur and Common Quail Coturnix coturnix - the two species for which spring hunting is allowed - are hunted in autumn than in spring. We show that statistics on the number of birds hunted in spring, which hunters are legally obliged to provide to authorities, are under-reported: they are not correlated, at times negatively correlated, with data on the daily influxes of birds, and they spike in the final week of the season, consistent with the hypothesis that hunters under-report to avoid reaching quotas which would result in an early season closure. Finally, while there are wide error margins around the numbers, independent annual estimates of turtle-doves hunted in Malta imply spring hunting is a conservation concern beyond the country itself. Each spring, hunters in Malta kill the equivalent of between $2.4 \%$ and $4.4 \%$ of Europe's turtle-dove population and $0.4 \%$ and $0.5 \%$ of its quail population.
\end{abstract}

\section{Introduction}

In late winter and spring, birds migrate from their wintering grounds in Africa to their breeding grounds in Europe. The European Commission's 1979 Wild Birds Directive bans member states from hunting wild birds during spring, as hunting in spring, before the birds have reproduced, is perceived to have a greater effect on bird populations than it would in autumn or winter, after they have reproduced. Some 170 species of these migratory birds pass over or stop in Malta while on their way to the European continent (Casha 2004).

Malta joined the European Union (EU) in 2004 and is a signatory to the Birds Directive (Directive 2009/I47/EC of the European Parliament and of the Council of 30 November 2009 on the conservation of wild birds). Despite this, Malta continued to allow a spring hunting season with no bag limit - after EU membership, on the grounds that no alternative hunting season existed. In 2009 the European Court of Justice found that from 2004 to 2007 Malta failed to uphold its obligation under the Birds Directive. It ruled that 'the spring hunting season in Malta ... resulted in a mortality rate for that period some three times higher for quails and eight times higher for turtle doves than for the autumn hunting season did not constitute an adequate solution 
that was strictly proportionate to the aim of conserving bird species' (EC 2009a). In response to this judgement, Malta developed a legal framework that allowed a derogation opening a spring hunting season for European Turtle-dove Streptopelia turtur and Common Quail Coturnix coturnix.

To set hunting bag limits for these birds, the Maltese government referred to the EU Management Plan for Quail 2009-2011, which classified the conservation status of quail as "favourable" in the EU, with the EU quail population numbering some 0.88-1.91 million calling males (EC 2009b, WBRU 2012b). For turtle-dove, the Maltese government referred to the EU's Management Plan for Turtle-Dove 2007-2009, which stated that the population of turtle-dove breeding pairs is around 1.6-2.6 million, meaning this species was considered to be "stable" in Central Europe, including in nearby Italy (EC 2007, WBRU 2012b). More broadly, however, the pan-European turtle-dove population is considered to be "unfavourable", based on the observation of decreasing trends in a number of EU states. Europe's 2012 turtle-dove population level is $21 \%$ of what it was in 1980 (EBCC 2014). Globally, BirdLife International (2014) classified both turtle-dove and quail populations as being in decline.

The legal framework Malta developed did not accurately reflect the wider conservation statuses of these birds, allowing hunters in Malta to kill too many of them under the terms of the Birds Directive. The European Commission made a formal warning to Malta in October 2010, asking Malta to comply with the Birds Directive or to go to back to the European Court of Justice and face financial penalties (EC 2010). Member states must apply for derogations every year, and reports to justify these derogations must be sent to the European Commission after the season closes. As such, Malta's legal framework was revised to respect the conditions demanded by a derogation from the Birds Directive after this warning.

Since 2010, Maltese hunters have been allowed to hunt up to 11,000 turtle-doves and 5,000 Common Quails each spring. These quotas are based on the birds' annual mortality rates. Hunters are also allowed to hunt unlimited numbers of both species in autumn, along with 39 other species, some of which are rare in Malta.

Malta justified its derogation from the Birds Directive under article 9.I(c) of the Birds Directive, which allows spring hunting if "there is no other satisfactory solution" and if hunting occurs "under strictly supervised conditions and on a selective basis, the capture, keeping or other judicious use of certain birds in small numbers" (EC 2009c). This derogation makes Malta the only EU member state to allow recreational bird hunting in spring. Other states have spring hunting derogations in the interest of "public health" (e.g. Finland) or "crop destruction" (e.g. Austria) (N2K Group 2011).

Given the birds' global and European conservation statuses, some maintain that Malta's quotas under its derogation are too high or that spring hunting there should not be allowed at all. While Malta's 9,754 licensed hunters remain defiant (WBRU 2014: 12), claiming that the numbers of birds they hunt does not have a significant negative effect on bird populations, NGOs have campaigned both in Malta and abroad to end or control spring hunting. The RSPB (2015), for example, described Malta's derogation as a "weakening of the Birds Directive" and its spring hunting season as "senseless slaughter". BirdLife Malta (2014), as well as the RSPB (2015), argued that illegal (under-reported) hunting during spring, a result of ineffective monitoring and enforcement, is a key reason as to why spring hunting should not be allowed. Spring hunting in Malta was also the subject of a debate in the UK House of Commons in 2014 (United Kingdom 2014). Most recently, in April 2015 Malta held a referendum on the abolition of spring hunting, with $50.44 \%$ of the electorate voting in favour of continuing spring hunting (BBC 2015).

Given the recent referendum result, Maltese governments are set to continue permitting spring hunting. It is important, therefore, to assess whether spring hunting is occurring under the terms of Malta's derogation to the Birds Directive. In this paper, we aim to contribute to the debate in two ways. First, to ask whether there is a basis for Malta's spring hunting derogation (that there is no alternative to the spring season), we compare official data on hunters' autumn and spring kills for all seasons from 2010 to 2014. Second, to test the hunters' argument that their number 
of kills does not have a meaningful impact on the birds' populations, we first looked at whether their self-reported kills are consistent with data on estimated daily influxes. We then give independent estimates of the scale of turtle-dove and quail hunting in Malta, comparing the estimates to Europe's total population levels.

\section{Methods}

\section{Comparing autumn and spring hunting}

Hunters in Malta were given a derogation that allows spring hunting on account of there being no other adequate alternative hunting season. To check whether this derogation is justified, we compared hunters' bag statistics (Carnet de Chasse) for the autumn season (start of September to end of January) and spring season (last three weeks of April) for turtle-doves and quails. The Maltese government's Wild Bird Regulation Unit (WBRU) legally obliges licensed hunters to complete and return Carnet de Chasse reports, stating how many of each species they trapped or shot. The WBRU publishes these reports online (WBRU 2010; 2011; 2012a; 2013a; 2014; $2015 \mathrm{~b}$ ). For the derogation to be justified, we would expect fewer birds to be shot or trapped in autumn, when there is no quota, than in spring, when there is a national quota of 11 ,ooo turtledoves and 5,000 quails.

\section{Under-reporting of spring hunting}

To assess whether there is an under-reporting bias in hunters' spring bag statistics, we first look at the temporal distribution of daily turtle-dove and quail catches, and their correlations with daily bird influx data. The WBRU legally obliges hunters to send a blank text message (SMS) from their mobile telephones, which they must carry with them while hunting, to a WBRU telephone number for turtle-doves and one for quails immediately after shooting a bird (WBRU 2014: 14). The licensed hunter is also obliged to declare each turtle-dove and quail they shot in their Carnet de Chasse. SMS data are available for the spring 2012, 2013, and 2014 seasons (WBRU 2012b, 2013b; 2014). The spring season is either closed on the last day of April or when the quotas have been reached (the quail quota is 5,000). During 2012-2014, the season was never closed early due to a full quota.

We expect shot bird reports to be positively correlated with the daily influx of turtle-dove and quail, since the main (but not only) limit on total kills is bird availability. Data on daily influxes for 2012, 2013, and 2014 are from independent reports produced by Ecoserv, an environmental consultancy, commissioned by the Malta Environment and Planning Agency (MEPA) and the WBRU (WBRU 2012b, Ecoserv 2013, WBRU 2014). The same method was followed for each year (see Ecoserv 2013: 14-6). During Ecoserv's survey, two individuals - a field assistant capable of identifying turtle-dove and quail, and an observer responsible for recording data in the field - are stationed at a total of 28 sites (or count stations) distributed over the islands of Malta, Comino and Gozo (national land area of $316 \mathrm{~km}^{2}$ ). Field assistants are recruited by Ecoserv, and are mostly students reading for science degrees at the University of Malta. No special skills are needed to identify quail or turtle-doves in flight. Quail monitoring is done by surveying fields with the aid of German pointer dogs. The survey is undertaken over a three-week period between 14 and 3o April. During the survey, counts of individuals of the two species are made at 10 different sites each day. Each group of sites is surveyed once every three days, such that a total of 28 sites are surveyed in total over each period of three days. Furthermore, the study site at Comino is included in the 10 sites surveyed on any one day, such that this site is surveyed on a daily basis; when weather conditions preclude surveys at the Comino site due to unavailability of sea transport services, they are undertaken at alternative proximate sites (in Armier or Qala) instead. The sampling sites do not change from one survey to the next. The count data are then used to calculate the mean number of birds recorded for each day of the survey. 
We then collected independent estimates - those not directly supplied by hunters - on hunted turtle-doves and quails in Malta, starting from the first estimate by Woldhek (1980) to the last by Fenech (1992). As discussed in Fenech (2010: 158-160), there is controversy surrounding these estimates, but they remain the standard reference point for the Maltese hunting debate. While there are wide error margins surrounding these estimates, they provide an alternative measure of the scale of hunting in Malta to the numbers supplied directly by hunters.

To place these estimates in context, we compared them to the European Commission's estimates of the birds' populations in the 2007-2011 period based on two separate EU reports. The European Commission's Management Plan for Turtle Dove, 2007-2009 report (EC 2007: 17) provides minimum and maximum estimates of turtle-dove breeding pairs in the European Union member states. We multiplied the sum of the minimum and maximum estimates by two to get maximum and minimum estimates of total turtle-doves in the European Union. For the quail estimates, the Management Plan for Common Quail, 2009-2011 (EC 2009b: 23) also provides minimum and maximum estimates of breeding pairs by member state. We again summed the minimum and maximum estimates, and multiplied them by two, to arrive at minimum and maximum estimates of the total number of quails in the European Union. These numbers are available in Table $\mathrm{S}_{1}$ in the online supplementary material. As can be seen, the reports' estimates refer to 1988 to 2003 for quails and 1979 to 2003 for turtle-doves. This range of years broadly coincides with the independent estimates of birds hunted in Malta, with the earliest year being 1980 and latest 1992.

\section{Results}

\section{A comparison of spring and autumn hunting statistics}

Table 1 indicates that in 2010 hunters reached $0.1 \%$ of the turtle-dove quota and $\% \%$ of the quail quota, when the season was opened for only six days, and to a limited number of hunters, due to pressure from the European Court of Justice (Gatt 2010). In 2011, the proportion for turtle-doves was $16 \% ; 7.3 \%$ in $2012 ; 28.9 \%$ in 2013 ; and $37.6 \%$ in 2014 . The respective numbers for quails are: $7.8 \% ; 3 \% ; 9.9 \%$; and $12.7 \%$.

The numbers of hunted birds are higher in autumn. Aside from 2010, when the spring season was shortened, hunters shot on average 2.5-times more turtle-doves and 14.3-times more quails in autumn than they do in spring.

Table 1. European Turtle-dove and Common Quail carnet de chasse (hunting bag) statistics. Carnet de Chasse are hunting bag booklets in which hunters are legally obliged to record their kills and then pass on the booklets to the authorities. 'Kills' are total number of hunted (shot or trapped) turtle-doves. 'Quota' is spring quota 11,000 of turtle-doves and 5,000 quails. Final column is proportion of spring kills of all annual kills. Spring 2010 season was open for 1o days and to a limited number of hunters. Autumn kill numbers from WBRU (2015b: 3). Spring kills for 2010 to 2013 from Carnet de Chasse reports; 2014 numbers from WBRU (2014: 17).

\begin{tabular}{lccccc}
\hline Year & Spring kills & \% quota & Autumn kills & Autumn/spring & \% shot in spring \\
\hline Turtle Dove & & & & & \\
2010 & 10 & 0.1 & 11,571 & 1157.1 & 0.1 \\
2011 & 1,762 & 16.0 & 4,302 & 2.4 & 29.1 \\
2012 & 805 & 7.3 & 3,696 & 4.6 & 17.9 \\
2013 & 3,175 & 28.9 & 7,857 & 2.5 & 28.8 \\
2014 & 4,131 & 37.6 & 2,483 & 60.1 & 62.5 \\
Quail & & & & & \\
2010 & - & 0.0 & 14,116 & - & 0.0 \\
2011 & 390 & 7.8 & 6,289 & 16.1 & 5.8 \\
2012 & 151 & 3.0 & 4,262 & 28.2 & 3.4 \\
2013 & 497 & 9.9 & 5,093 & 10.2 & 8.9 \\
2014 & 637 & 12.7 & 1,689 & 2.7 & 27.4 \\
\hline
\end{tabular}


In other words, of the total annual number of hunted turtle-doves and quails, an average of $34.5 \%$ and $11.4 \%$ respectively were hunted in the springs of 2011 to 2014 . A t-test for the difference in means between the post-2010 spring and autumn seasons yields a mean difference of $-2,116$ turtle doves and of $-3,914$ quails (turtle doves: $t=-1.54, \mathrm{df}=6, P$-value $=0.086$; quails: -3.99 , $\mathrm{df}=6, P$-value $=0.004)$.

\section{Daily numbers of hunted and observed turtle-doves and quails}

The daily cumulative number of hunted turtle-dove and quail spiked in the final days of each spring season from 2012 to 2014, having accelerated at the end of April (Figure 1). Turtle-dove catches in the final week of 2012 accounted for $88 \%$ of all catches that year; $82 \%$ in 2013 ; and $78 \%$ in 2014. For quail, the respective numbers were $64 \%, 86 \%$, and $72 \%$.

The pattern in figure $I$ is inconsistent with the data on daily influxes and for both species, the series on hunted birds diverges from that on influxes in the final week of the season (Figure 2)

More systematically, the strength of the relationships between the daily reported catches and the influx of birds each day is extremely low (Table 2). The only significant correlation between numbers of birds reported shot and observed on the ground was a positive relationship for Turtle Dove in 2012. (coef. $=0.029 \pm 0.007 \mathrm{SE} ; P=0.002 ; n=16$ ); $\mathrm{R}^{2}=0.51$ ). There were no other significant coefficients. When combined across all years, there was a correlation coefficient of 0.04 and an $R^{2}$ of 0.16 . For the quail data, there were no significant regression coefficients or correlation coefficients. The pooled estimation across all years yielded a negative coefficient (coef. $=-0.012$; SE $\pm 0.0018 ; P$-value $=0.51 ; n=53 ; R^{2}$ of 0.0087 .

According to estimates provided by the literature, the mean number of hunted turtle-doves ranges from 108,284 (lowest estimate) to 264,000 (highest), while the respective numbers for quails are 8,327 (lowest estimate) and 11,250 (highest) (Table 3).

The final row shows that the numbers of hunted turtle-doves in Malta were equivalent to between $4.5 \%$ and $6 \%$ of the European Union's total turtle-dove population. Alternatively, expressed with only the Italian turtle-dove population as a denominator (between 100,000 and 200,000 turtle doves [EC 2007: 17]) - Italy is Malta's nearest European Union neighbour, and is on the same Mediterranean bird migratory route - the ratio is between $108 \%$ and $132 \%$. The numbers of hunted quails in Malta were equivalent to $0.5 \%$ and $0.4 \%$ of the European Union's quail population. In other words, this is equivalent to $167 \%$ and $56 \%$ of Italy's quail population (between 5,000 and 20,000 quails [EC 2009b: 23]) or $771-1,042 \%$ of UK's quail population (latest estimate is 540 males, which we multiplied by two [Musgrove et al 2013).

\section{Discussion}

By exploring statistics on hunted turtle-doves and quails and their daily influxes during Malta's hunting seasons, we arrived at three main results. First, greater numbers of both species are reported
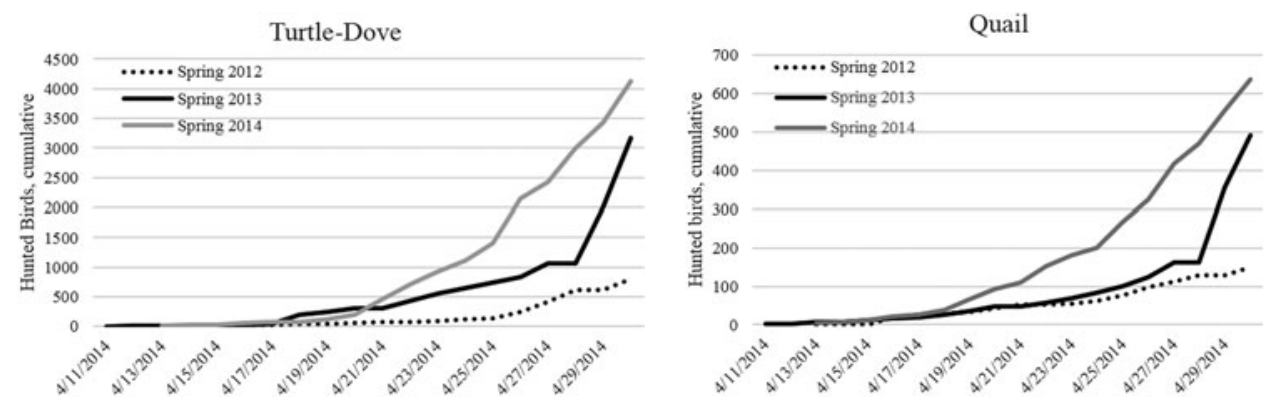

Figure 1. Cumulative catches of turtle-dove and quail in Maltese spring seasons. 

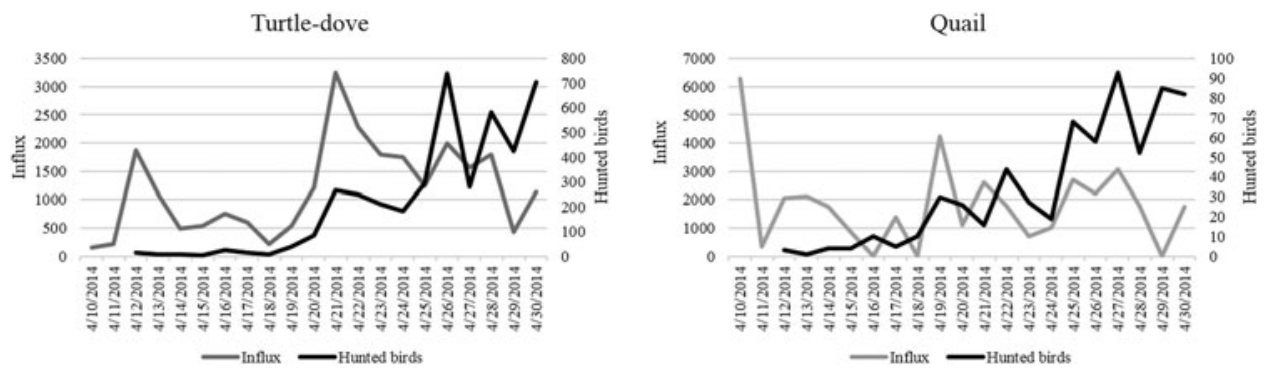

Figure 2. Daily influx of birds and catches of birds in Maltese 2014 spring season.

to be hunted in autumn than in spring. Second, the number of birds hunted, which hunters are legally obliged to provide to authorities, are under-reported. They are not correlated, at times negatively correlated, with data on the daily influxes of birds, and they spike in the final week of the season, consistent with the hypothesis that hunters under-report to avoid reaching quotas, thus resulting in an early season closure. Third, while there are wide error margins around the numbers, independent annual estimates of turtle-doves hunted in Malta imply spring hunting is a conservation concern beyond the country itself.

Each result has a distinct implication for how spring hunting and conservation policy is conducted in Malta. In a referendum on the abolition of spring hunting in April 2015, 50.44\% of the Maltese electorate voted in favour of continuing spring hunting (BBC 2015). While this vote consolidated domestic support for the practice, our results imply that spring hunting should not happen under the terms of the Birds Directive. The Birds Directive only allows derogations, under article 9.1, where there is "no other satisfactory solution...to permit under strictly supervised conditions and on a selective basis, the capture, keeping or other judicious use of certain birds in small numbers" (EC 2009c).

The first result, that more birds are hunted in autumn than in spring, runs contrary to the basis of Malta's derogation from the European Commission's ban on recreational spring hunting. Malta's derogation of the European Commission's ban can only be legally permissible, under article 9.I of the Birds Directive, if "no other satisfactory solutions" to spring hunting exist (EC 2009c). The numbers in Table I provided by the hunters themselves, show that there are sufficient birds for hunters to shoot in autumn. Hunters are allowed to hunt $4 \mathrm{I}$ species in unlimited numbers during the five-month autumn season. The autumn season as it stands is an alternative solution.

Second is the result that hunters appear to be under-reporting their number of kills. Another condition for Malta's derogation on spring hunting is that, under article 9.I(c) birds are hunted

Table 2. Ordinary-least-squares correlations of daily influx and self-reported catch data in spring seasons. Coefficient is response in self-reported catch SMS data to influx data. $\mathrm{N}$ is number of days in each spring season.

\begin{tabular}{lllllllr}
\hline Turtle-dove & Coefficient & Standard error & $P$-value & $\mathrm{R}^{2}$ & $N$ & F-statistic & Pearson correlation \\
\hline 2012 & 0.029 & 0.007 & 0.002 & 0.512 & 16 & 14.68 & 0.72 \\
2013 & -0.025 & 0.043 & 0.565 & 0.021 & 18 & 0.34 & -0.15 \\
2014 & 0.117 & 0.069 & 0.108 & 0.144 & 19 & 2.87 & 0.38 \\
All & 0.0065 & 0.022 & 0.775 & 0.0016 & 53 & 0.08 & 0.04 \\
Quail & & & & & & \\
2012 & 0.0003 & 0.0009 & 0.74 & 0.008 & 16 & 0.11 & 0.09 \\
2013 & -0.0032 & 0.0033 & 0.34 & 0.057 & 18 & 0.97 & -0.24 \\
2014 & 0.0059 & 0.0066 & 0.383 & 0.045 & 19 & 0.8 & 0.21 \\
All & -0.0012 & 0.0018 & 0.508 & 0.0087 & 53 & 0.45 & -0.09 \\
\hline
\end{tabular}


Table 3. Annual estimates of hunted birds in Malta and European Union populations. Average is the mean of the independent estimates. EU Population is the total number of birds in the European Union. Farrugia (1988) claims hunters shot nine turtle-doves and one quail each, and trappers caught an average of seven turtle-doves each. In 1988, there were 15,947 licensed hunters, resulting in a total of 144,001 turtle doves and 19,136 quails (lowest). Adding trapped turtle-doves, using the 1995 figure, then the number of turtle doves trapped amounted to 5,700 , bringing the collective spring bag of 149,701 (lowest).

\begin{tabular}{|c|c|c|c|c|c|}
\hline \multirow[b]{2}{*}{ Study } & \multirow[b]{2}{*}{ Year } & \multicolumn{2}{|c|}{ Turtle-dove } & \multicolumn{2}{|l|}{ Quail } \\
\hline & & Lowest & Highest & Lowest & Highest \\
\hline Woldhek (1980: 26) & 1980 & 20,000 & 200,000 & 1,000 & 5,000 \\
\hline Sultana and Gauci (1982: 26) & 1982 & 120,000 & 240,000 & 4,000 & 5,000 \\
\hline Magnin (1986: 29-31) & 1986 & 100,000 & 200,000 & 1,500 & 3,000 \\
\hline Farrugia (1988), estim. & 1988 & 149,701 & & 19,136 & \\
\hline Sultana (1991: 162) & 1991 & 100,000 & 200,000 & & \\
\hline Fenech (1992: 74-77) & 1992 & 160,000 & 480,000 & 16,000 & 32,000 \\
\hline Average & & 108,284 & 264,000 & 8,327 & 11,250 \\
\hline EU Population & & $4,602,224$ & $6,034,410$ & $1,608,332$ & $3,167,976$ \\
\hline Average/EU Population & & $2.35 \%$ & $4.37 \%$ & $0.52 \%$ & $0.36 \%$ \\
\hline
\end{tabular}

"under strictly supervised conditions" (EC 2009c). The statistics in table 2 and in figures 1 and 2 imply that hunting in Malta is not taking place under "strictly supervised conditions". Perhaps these results should not surprise us. BirdLife Malta revealed that Malta's main hunting federation (the FKNK), in a statement posted on its internet forum on 4 April 2012, a day after the announcement of the spring hunting season, warned its members to "be careful" when reporting their kills to "because if everyone catches one bird and sends an SMS, the season will close" (Times of Malta 2012). While monitoring efforts have recently improved, our result implies that more resources are needed to supervise and enforce spring hunting policies in Malta, if the practice is to continue. The mean daily enforcement deployment of WBRU officers in the field during spring hunting hours went from 61 in 2012, to 72 in 2013, and 85 in 2014 (WBRU 2015a). By comparison, the number of licences for hunting birds on land over these years averaged 10,000 (WBRU 2015a).

Third is the result that independent estimates of hunted birds are higher than those supplied by hunters. Another condition for Malta's derogation, again under article 9.I(c), is the "judicious use of certain birds in small numbers" (EC 2009c). While the numbers in table 3 are estimates, they indicate that hunting in Malta might be of conservation concern beyond the country itself. This fits with previous work that emphasises the importance of hunting pressure in southern Europe for the Continent's bird population trends (Fasolo et al. 2010). Indeed, ringing recoveries indicate that turtle-doves shot in Malta in spring originate from Italy, the Czech Republic, Germany, and Poland (McCulloch et al 1992, Raine 2007, Fenech 2010). The majority of quail recovered in Malta (94.4\%), were ringed in Italy and there is a single recovery of a bird from Hungary (Raine 2007). Only 37 ringed turtle doves and 19 quails have been recovered in Malta (Raine 2007). Ringing provides an indication of where the birds originate from but does not give a watertight set of data because ringing effort varies from country to country and certain species, such as turtle-dove and quail, do not feature prominently in the number of birds ringed in any country, particularly so for quail, as a specific effort is needed to catch them. The fact that most quails recovered in Malta come from Italy also reflects the ringing effort made in Italy to ring quail. It is also likely that few hunters report shot ringed birds.

The April 2015 referendum, in which 50.44\% of the electorate voted in support of spring hunting, means the practice is set to continue, for even though there will be concerns around the revised status of the turtle-dove, which is now on the red list in Europe, it is likely that there will still be a spring hunting season for quail, because the status of quail has remained unchanged. Malta's 10,00o licenced hunters form a politically influential lobby group in a country whose electorate numbers around 330,000 voters, and where general elections are usually won or lost on close 
margins. Still, the Maltese government has a commitment to its electorate as well as the Birds Directive, as do other European Union member states. The results we presented in this paper indicate that Malta is failing in its commitment to the Birds Directive. The burden of evidence to show that the spring derogation does not affect the already-deteriorating conservation status of these birds, and that the spring season is strictly supervised, is on the Maltese government.

\section{Postscript}

In spring 2015, the SMS system was replaced by a mobile telephone system. Hunters had to register a mobile telephone number with their hunting licence and were expected to immediately report their catches through a telephone reporting system and through their Carnet de Chasse book before leaving the hunting zone. Hunters were also expected to abide by the time restrictions and respect the daily bag limit of two birds and a season bag limit of four birds. The special licence obtained by hunters to hunt in spring stipulated that hunters had to call telephone number 27790299 via their mobile telephones immediately after shooting a bird. The telephone system subsequently guided the hunters through the reporting procedure via voice prompts. Each telephone report was registered in the database in real time, and the hunters concerned received an SMS confirmation of a successful report. The system could only be used by hunters in possession of a Special Licence, and did not allow any reports from unlicensed persons. While the system shows an improvement in reporting over the SMS system, it is evident there are still discrepancies between the number of birds seen and those reported shot according to the latest 2015 derogation report. Further, the system still relies on the good will of hunters to report accurately what they shoot. The whole reporting system is set to change, as a call for tenders has been issued for the design and implementation of a hunting and trapping licensing and telephone game reporting system that can also record the approximate geographic location of the caller. Further, the calls will be split according to the type of licence carried by the caller and the applicable daily or seasonal quotas for each licensee. The caller will be reminded of his quota obligations via a voice prompt. Reports will only be accepted during any season for species that can be hunted or captured during that particular season. If the national quota for a particular species is reached in any given season, the system will notify all holders of licences for this species by means of SMS that the quota has been reached and no further reports of these species are accepted.

\section{Supplementary Material}

The supplementary materials for this article can be found at journals.cambridge.org/bci

\section{References}

BBC (British Broadcasting Corporation) (2015) Hunters win Malta bird referendum on shooting ban. Online: http://www.bbc.com/ news/world-europe-32274233. Accessed: 10 July 2015.

BirdLife International (2014) Datazone. Online: http://www.birdlife.org/datazone/. Accessed: 21 Jan 2015.

BirdLife Malta (2014) Briefing: Malta's derogation of the Birds Directive for the spring hunting of Quail and Turtle Dove. Online: http://www.birdlifemalta.org/photos/ otherfiles/5814.pdf. Accessed: 4 Feb 2015.
Casha, A. (2004) Where to watch birds and other wildlife in Malta. Malta: BirdLife Malta.

EBCC (European Bird Census Council) (2014) Trends of common birds in Europe, 2014 update. Online: http://www.ebcc.info/index. php?ID=557. Accessed: 2 Feb 2015.

EC (European Commission) (2007) Management plan for Turtle Dove (Streptopelia turtur) 2007-2009. Online: http://ec.europa. eu/environment/nature/conservation/ wildbirds/hunting/docs/turtle_dove.pdf. Accessed: 4 Feb 205. 
EC (European Commission) (2009a) Environment: Court confirms that spring hunting in Malta is in breach of EU law. Online: http://europa.eu/rapid/press-release_IP-o91301_en.htm. Accessed: 4 Feb 2015.

EC (European Commission) (2009b) European Union Management Plan 2009-2011: Common Quail, Coturnix coturnix. Online: http://ec.europa.eu/environment/nature/ conservation/wildbirds/hunting/docs/ Quail\% 20EU_\% 2oMP.pdf. Accessed: 4 Feb 2015.

EC (European Commission) (2009c) DIRECTIVE 2009/147/EC OF THE EUROPEAN PARLIAMENT AND OF THE COUNCIL of 30 November 2009 on the conservation of wild birds (codified version). Online: http://eur-lex.europa.eu/legal-content/ EN/TXT/HTML/?uri=CELEX:32009Lo147 $\&$ from $=$ EN. Accessed 10 July 2015.

EC (European Commission) (2010) Environment: Commission requests Malta to comply with Court ruling on bird hunting. Online: http://europa.eu/rapid/pressrelease_IP-10-1409_en.htm?locale $=$ enAccessed: 28 October 2010.

Ecoserv Ltd (2013) Report on a survey of the influx of migratory Common Quail and Turtle Dove over the Maltese Islands, made in April 2013. Online: https://environment. gov.mt/en/Documents/Downloads/WBRU/ WBRU\% 20-\% 206B.\% 20Reports \% 20 and \% 20Statistics \% 20(Report \% 201B).pdf. Accessed: 21 Jan 2015.

Farrugia, C. L. (1988) Statistika realistika. Mid-Dura Bullettin Ufficjali tal Ghaqda Kaccaturi Nassaba Konservazzjonisti No 4. November.

Fasolo, M., Rubolini, D., Merli, E., Boncompagni, Eö and Bressan, U. (2010) Long-term trends of heron and egret populations in Italy, and the effects of climate, humaninduced mortality, and habitat on population dynamics. Population Ecol. 52: 59-72.

Fenech, N. (1992) Fatal flight: the Maltese obsession with killing birds. London: Quiller Press.

Fenech, N. (2010) A complete guide to the birds of Malta. Malta: Midseabooks.

Gatt, B. (2010) Malta to hold short spring hunting season despite court ruling, Bloomberg, April 9, 2010. Online: http://www.bloomberg. com/news/articles/2010-04-09/maltato-stage-short-spring-hunting-seasondespite-european-court-ruling. Accessed 6 July 2015.

Magnin, G. (1986) An assessment of illegal shooting and catching wild birds in Malta. Cambridge, UK: International Council for Bird Preservation. (ICBP Study Report No. 13).

McCulloch, M. N., Tucker, G. M and Baillie, S. R. (1992) The hunting of migratory birds in Europe: a ringing recovery analysis. Ibis 134(S1): 55-65.

Musgrove, A. J, Aebischer, N. J, Eaton, M. A., Hearn, R. D., Newson, S. E., Noble, D. G., Parsons, M., Risely, K. and Stroud, D. A. (2013) Population estimates of birds in Great Britain and the United Kingdom. British Birds 106: 64-100.

$\mathrm{N}_{2} \mathrm{~K}$ Group (2011) Composite European Commission Report on Derogations in 2008 According to Article 9 of Directive 79/409/ EEC on the Conservation of Wild Birds, prepared for the European Commission, Directorate General Environment, B2 Unit in the framework of the Service Contract No.070307/2007/488316/SER/B2, September 2011. Online: http://ec.europa.eu/environment/nature/knowledge/rep_birds/docs/ derogation_report_2008.pdf. Accessed: 6 July 2015.

Raine, A. F. (2007) The international impact of hunting and trapping in the Maltese islands. BirdLife Malta. Online: http://www. birdlifemalta.org/photos/otherfiles/206.pdf. Accessed 2 February 2015.

RSPB (Royal Society for the Protection of Birds) (2015) Mark your calendars: We are Shouting NO more spring hunting in Malta on April 11 2015. Online: http://www.rspb. org.uk/community/ourwork/b/biodiversity/ archive/2015/01/22/mark-your-calendarswe-are-shouting-no-more-spring-huntingin-malta-on-april-11-2015.aspx. Accessed: 4 Feb 2015.

Sultana, J. (1991) Malta Ornithological Society: A bird protection society in a hostile environment. In T. Salathe, ed. Conserving migratory birds. Cambridge, UK: International Council for Bird Preservation. (ICBP Technical Publication No. 12). 
Sultana, J. and Gauci, C. (1982) A new guide to the birds of Malta. Valletta, Malta: The Ornithological Society.

Times of Malta (2012) BirdLife reveals FKNK 'instructions' to hunters, Saturday, April 7, 2012. Online: http://www.timesofmalta. $\mathrm{com} /$ articles/view/20120407/local/birdlifereveals-fknk-instructions-to-hunters. 414462. Accessed: 4 Feb 2015.

UK (United Kingdom) (2014) Parliamentary Debates, House of Commons. Migratory Birds (Malta). 7 May 2014: Column 122WH. Online: http://www.publications.parliament.

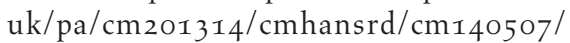
halltext/140507hooo2.htm. Accessed: 4 Feb 2015.

WBRU (Wild Bird Regulation Unit) (2010; 2011; 2012a; 2013a) Carnet de Chasse Reports. Online: https://environment.gov. $\mathrm{mt} / \mathrm{en} /$ Pages/WBRU/Reports-and-Statistics. aspx. Accessed: 2 Feb 2015.

WBRU (Wild Birds Regulation Unit) (2012b) Report on the Outcome of the 2012 Spring Hunting Season in Malta. Online: https:// environment.gov.mt/en/Documents/ Downloads/WBRU/Malta \% 20Spring\% 20 Hunting \% 2oDerogation \% 20Report \% 20 2012.pdf. Accessed: 21 Jan 2015.

WBRU (Wild Birds Regulation Unit) (2013b) Report on the Outcome of the 2013 Spring
Hunting Season in Malta. Online: https:// environment.gov.mt/en/Documents/ Downloads/WBRU/WBRU \% 20-\% 20 6A. \% 20 Reports $\%$ 2oand $\%$ 2oStatistics $\% 20$ \% 28Report\% 201A\% 29.pdf. Accessed: 21 Jan 2015.

WBRU (Wild Birds Regulation Unit) (2014) Report on the Outcome of the 2014 Spring Hunting Season in Malta. Online: http:// environment.gov.mt/en/document $\% 20$ repository/wbru/derogation $\%$ 2oreport $\% 20$ 2014.pdf. Accessed: 21 Jan 2015.

WBRU (Wild Birds Regulation Unit) (2015a) Overview of the 2014 autumn hunting season and preliminary assessment of enforcement policy measures. Online: https:// environment.gov.mt/en/government/ Press\% 2oReleases/Documents/2015/ pr150447a.pdf. Accessed: 10 July 2015.

WBRU (Wild Birds Regulation Unit) (2015b) Report on the Outcome of the 2015 Spring Hunting Season in Malta. Online: https:// environment.gov.mt/en/Documents/ Downloads/WBRU/spring\% 2ohunting \% 20 2015/SH\% 202015\% 20derogation \% 20 report.pdf. Accessed: 23 July 2015.

Woldhek, S. (1980) Bird killing in the Mediterranean.Zeist: European Committee for the Prevention of Mass Destruction of Migratory Birds.

\section{PAUL CARUANA-GALIZIA* Germany \\ NATALINO FENECH \\ University of Malta, Tal-Qroqq, MSD 2080 Msida, Malta \\ ${ }^{*}$ Author for correspondence; email: caruanap@hu-berlin.de}

Institute of Economic History, Humboldt-University of Berlin, Spandauer strasse 1, 10178 Berlin,

Received 7 April 2015; revision accepted 15 October 2015 